\title{
ОБЗОРЫ
}

UDC 7.03

\section{"The Silver Age" Spiritual Culture as the Foundation of the 125-year Development of the Gnesin System of Education}

\author{
G. V. Mayarovskaya, L. S. Zorilova, D. G. Rodionova \\ Gnesins' Russian Academy of Music, \\ 30-36, Povarskaya ul., Moscow, 121069, Russian Federation
}

For citation: Mayarovskaya, Galina, Larisa Zorilova, and Daria Rodionova. “The Silver Age’ Spiritual Culture as the Foundation of the 125-year Development of the Gnesin System of Education". Vestnik of Saint Petersburg University. Arts 10, no. 3 (2020): 507-517. https://doi.org/10.21638/spbu15.2020.308

In this article, the 125-year history of the Gnesin system of musical education is examined. The thread that runs through its long history is the spiritual culture of the Silver Age with its traditions, values, outstanding teachers, as well as both performers and talented leaders. The Gnesin family highly valued the concepts of the Silver Age. They managed to create an inimitable system of musical education that is marked by its patriotic way of thinking, devotion to music, and loving attitude towards students. The article focuses on the figure of Elena Gnesina who was drawing herself on the high spiritual culture of the Silver Age and devoted herself entirely to the music, demonstrated her commitment to the students, and protected them even in the most difficult times regardless of the social environment: revolutions, the First and Second World Wars. The passion for her work, which Gnesina demonstrated throughout her 72-year life, has been reverently passed from generation to generation by the Gnesin system's teachers. Nowadays, all educational institutions - the school, two colleges and the institute continue to accumulate spiritual traditions, constantly giving rise to new fields and profiles of professional education that respond to the challenges of the time and strengthen the position of the Gnesin system of education both in Russia and abroad.

Keywords: spirituality, music, art, values, traditions, the Silver Age, creation, education, the Gnesin system, Elena Gnesina.

Russian spiritual culture has developed a rich and valuable heritage during its history. Being passed down throughout generations in various social circumstances, at all times it has opened new horizons for its further development and advancement. Russian spiritual culture, based on people's mentality, local traditions, spiritual and moral commandments, has cooperated with the global culture, influencing it by its best scientific, technical achievements, as well as achievements in art.

(c) Санкт-Петербургский государственный университет, 2020 
At all times, the spiritual culture was fundamental for the development of artistic creations that attested to its highest attainable level of excellence. An essential part of this process was the period of the Silver Age, which covers the end of $19^{\text {th }}$ - beginning of the $20^{\text {th }}$ centuries. The Silver Age, that Russian philosopher Nikolai Berdyaev called the "Russian Renaissance", reveals many of the mysteries of the unknown, unique, breathtaking, and inimitable nature. "...The musical culture of Russia was formed in an atmosphere of confrontation between the old and the new, traditions and innovation" [1, p. 8].

Russian spiritual culture, as well as other arts of this period, attained the highest level of development and challenged the routine of the earthly world. Art and culture were faced with an ambitious task to create a totally new elevated mode of life, to lift the nation's spirit, to change the world, and to produce creations that would be patterns of the spiritual excellence. That was the beginning of the tragic and sublime period of the Silver Age that gave way to the spiritual and creative search of prominent figures in the fields of art and culture. Over time, a vast number of highly artistic masterpieces have made their way to the present day. They make us look at the modern conception of the world, attitudes toward people, and art from a different angle, enabling us to observe our strengths and weaknesses and to figure out the best way of advancing further. It is in the period of the Silver Age that an individual, one's inner spiritual world, attitudes, actions, spiritual values, and search for Love, Freedom, Goodness, and Beauty ideals become of central importance in Russia. These ideals gained more and more attention among writers, poets, artists, and musicians. These supreme values asserted the "gold standards" of excellence in life, art, and culture and combined with the primitive beauty of the world and its divine perception. The latter were opposed to everything malign, vulgar, and retrogressive.

The period of the Silver Age exercised tremendous influence on the emergence of Russian art of music. It gave rise to a reassessment of the aesthetical conceptions and values and encouraged new ideas. Musicians' creative search was significant for a reassessment of conceptions and appraisal criteria of the previous century. It all stirred up controversy and contradictions of the conventional with the modern and encouraged further searching. The conventional school was represented by prominent figures, such as Nikolai Rimsky-Korsakov, Anatoly Liadov, Alexander Glazunov, Anton Arensky, Sergei Taneev, and Mikhail Ippolitov-Ivanov. In the early 1900 the most notable exponents of innovative ideas were outstanding creators of the Silver Age, such as Alexander Scriabin (symbolism), Nikolai Metner (neo-classicism), Sergei Rachmaninoff (neo-romanticism), Igor Stravinsky (neo-folklorism), and Sergei Prokofiev (cubo-futurism). They all were in search of new characters and means of musical expressiveness and they strove to mirror the changing world in their creations. It should be said, that the social environment of those times was quite complex, public opinion was not unique and integrated, various political trends emerged, and there was a general air of impending catastrophes. These gave way to new solutions to the problems of freedom and equality alongside the economic and spiritual crisis. It is not by chance, that Berdyaev noted the following about this period, "Never have temptations and confusions among people been so intense. Russian souls were possessed by the apprehension of irreversible catastrophes. The poets saw not only the forthcoming spring of the day, but also something dreadful, impending to Russia and the whole world. Religious philosophers became imbued with apocalyptic sentiments" [2, p.77]. "The end-of-days prophecy may have meant not the end of the world, but the end 
of imperial Russia $\langle\ldots\rangle$. There was nothing firmer and more stable in those times" [2, p. 154-5].

During this period the Russian system of music education was developing and strengthening, the most prominent in it being The Russian Musical Society that was afterwards renamed into The Imperial Russian Musical Society. The latter contributed significantly to the development of musical culture by supporting musicians' creativity and organizing a stable system of music education.

According to Tatiana Zima, The Imperial Russian Musical Society were involved in two main tasks: "1) to educate the population with a the taste for classical music (through concert activities) and 2) to train the domestic professional musician (through the building of musical educational institutions" [3, p. 10].

In 1862 the Saint Petersburg Conservatory and in 1866 the Moscow Conservatory were founded by the Rubinstein brothers [4].

And in this controversial environment of the Silver Age, which combined both a spiritual Renaissance and social confusion, the establishment of the world-renowned Gnesin system of musical education was begun 125 years ago. It should be noted that its history was not simple.

In 1895, having graduated from the Moscow Conservatory, pianists and sisters Elena and Maria Gnesina founded the Gnesin Musical School [uchilishche] where both children and adults could study from its inception. The Gnesin sisters played a prominent role in establishing this unique educational institution. There were no stages of education that are commonplace today (elementary, secondary, and higher), but the idea of the continuity of the educational process could already be noticed at the newly established institution. Throughout its history, special attention was given to children's general musical education from an early age.

According to the recollections of contemporaries, this school was distinguished by strict requirements, which was the reason why it was often called a "small conservatory". The young and talented Gnesin sisters strove to pass their experience, gained at the Moscow Conservatory, on to their students. The private music school, for more than 60 years, was located at the sisters' lodging. It should be noted, that the organization of the college was influenced by Russian spiritual culture, ideas of the Silver Age, creativity, high professionalism, charity, and the level of culture that the highly educated Gnesin family obtained.

Among Gnesins' friends were writers, artists, actors, and directors. The elder Gnesin sister, Evgeniya, was friends with the founder of the first people's theater Alexander Fedotov and with Konstantin Stanislavski, who formed the first troop of the future Moscow Art Theatre, known then as the Moscow Art-Public Theatre. "Art-Public" meant that each creative and talented individual could become an actor. It also displayed Russia's aspiration of the intelligentsia to pass their art to the general public. A concept of charity, bound up with the idea of common availability, opened the door to everyone wishing to exhibit their creative abilities, to perceive, explore, master, and enjoy art, to refine their inner spiritual world. In 1890, the Gnesins' house hosted a coterie, which included conservatory graduates. Together they organized charity performances that combined creative music episodes with theatrical humorous ones. The Gnesin sisters actively participated in both the work of the coterie and numerous educational and charity concerts in support of diseased and destitute people, children, and students. These concerts were conducted with 
the help of famous singers and musicians, such as Leonid Sobinov, Pavel Khokhlov, and Anna Knipper. The Gnesin sisters actively participated in these events after the foundation of the People's conservatory in Moscow in 1906 [5].

It is in this conservatory that Elena Gnesina managed to manifest her creative and administrative qualities. At that time, she was the head of the musical school. One of her main activities involved trying to engage teachers of the People's conservatory in charitable activities. It should be pointed out that Gnesina turned the college from a small homeschool into the largest complex of all levels of music education in the country. During her service as the head of educational institutions, Gnesina proved herself to be not only a teacher who treats young musicians with a gentle hand, but also a brilliant musician, instructor, and curator of the educational institution. Not only did she supervise the internal work of her colleagues within the walls of the college, but she also promoted the internal creative activity of individual performers and creative on-stage performance groups in the society.

The largest of her "managerial" projects was the organization of the first children's concert choir in 1903 under her sister's, Evgeniya Savina-Gnesina, supervision. This orchestra strongly influenced the entire society and gave way to the extensive development of the children's choir performance and further on children's plays, that were as a rule charitable in their nature. Thus, in 1911 the children's opera the "Dream of the Christmas Tree" was composed on the music of Alexander Gretchaninov and for first time, composing classes for children were launched. This all proves that the Gnesin family was actively participating in the musical education of children. They deeply believed that this period plays the same important role in a musician's life as the period of studying at college or university does. In music, she aspired to draw on established traditions and Russian spiritual culture, "<...> in an effort to bring music and the human sole together by way of comprehensive development of musical education, performance, and enlightenment, Elena Gnesina was unmatched" [6, p. 160].

The activities performed by the Gnesin sisters were not limited to pedagogy, they also performed music, and engaged in the public life of the country. Thus, in 1909 Evgeniya and Elizaveta Gnesin co-founded the Moscow scientific educational society the Taneev Research Music Library. Other Gnesin school teachers were also among the co-founders of the society, namely Reinhold Gliere, Mikhail Ippolitov-Ivanov, Konstantin Igumnov, Alexander Goldenweiser, Alexander Gretchaninov, Georgii Konius, Leonid Sabaneev, Nikolai Metner, Elena Bekman-Shcherbina, etc.

In the archives of the Gnesin' house there is a correspondence of the Gnesin family with their closest friend and colleague Reinhold Gliere, which reveals the rich inner spiritual world of these musicians, a touching, caring relationship with each other and the desire to always help as well as support the most difficult minutes of life, including during the war years [7].

The Gnesin sisters' educational activity and their sophisticated creations made a significant impact on Russian spiritual culture. They were faced with the administrative task of organizing and conducting various events: concerts, lectures, and numerous discussions on musical art. The most detailed and comprehensive creative activity of the Taneev Research Music Library is described in the papers of Elena Gnesina’s Memorial Museum-Apartment. 
Another educational society the Gnesin family (including Elena Gnesina) was engaged in was the club of Russian music fans. In this creative team, Nikolai Metner, Sergei Rachmaninoff, Alexander Scriabin, Lev Oborin, Alexander Goldenweiser, Heinrich Neuhaus, Maria Yudina, Ksenia Dorliak, and Sviatoslav Richter were also engaged. They performed their musical creations in front of children and the whole society. The tradition of performing, sometimes the toughest creations, in front of the students became a hallmark of the Gnesin school at each level of education [8].

Among Russian music fans were not only musicians, but also artists, poets, writers, dancers, and actors, such as Vyacheslav Ivanov, Vladimir Solovyov, Leonid Pasternak, Konstantin Balmont, Konstantin Stanislavsky, Vsevolod Meyerhold, and Alexander Blok. They were friends with the Gnesin sisters as well as their brother Mikhail Gnesin, who studied the antique musical world and focused on the art of sound, word, and intonation [9].

In his work "Examples of Musical Reading," he in accordance with the ancient Greek metrics introduced a term of "unequal length" of vowels, which meant that a stressed syllable's length was doubled. On the basis of the antique prosody, he stated that if the long syllable was pronounced in a long-drawn-out manner, it becomes melodious as far as it goes [I, p.6]. Gnesin's creative activity was supported by symbolist poets. He was interested in arts fusion and in this he was assisted by creative connections in the spheres of philosophy, history, literature, theatrical art, and by ideas that were advocated by the Silver Age exponents. Especially influential on the Gnesin family were Boris Pasternak, Konstantin Balmont, and Alexander Scriabin. What united their families was the pursuit of something elevated, new, and flawless. For instance, Scriabin lived with his family at Bolshoi Nikolopeskovsky pereulok, close to Gnesins' house on the Sobachia ploshchadka. They often met with each other. Scriabin's children Ariadna and Julian attended the Gnesin school. Elena Gnesina was in the conservatory together with Scriabin. She had a good understanding of his aspirations and admired his genius. They were friends with the poets Pasternak and Balmont. In the memorial museum-apartment of Scriabin, the Gnesin house, and the Literary Museum of Konstantin Balmont, much evidence can be found, from photos and pictures to remarks, comments, and adoring dedications to each other. Thus, on the photo of Scriabin taken during the last month of his life, a friendly and warm inscription, dedicated to Elena Gnesina can be found, "With a reproach for indulging the kids too much from their faithful creator". A ticket to Scriabin's concert and a program book was attached to the photo [II].

The Silver Age geniuses were closely bound to each other. They openly acknowledged each other's perfection and learned from each other. Thus, Balmont writes about music and Scriabin about poetry:

Tonchaishii zvuk, otkuda ty so mnoi?

Ty sozdan ptitsei, zhenshchinoi, strunoi?

Byt' mozhet, Solntsem? Ili tishinoi?

Konstantin Balmont [10]
The finest sound, what your nature is?

Who made you - woman, bird, or string?

Or maybe you were work of sun or peace?

(Translation K. Shulekina)

"Music $\langle\ldots\rangle$ reveals so many things in the understanding of poetry, I think that only a musician truly understands poetry". Alexander Scriabin [11, p. 309].

Music and poetry, as well as a composer and a poet, share much in common. A composer sees the world through the eyes of a poet, and, on the contrary, a poet perceives the 
world through the prism of sounds. Scriabin believed that the world can be compared to an ocean, which "consists of a mass of drops, each of them being the same creative imagination, as the ocean itself" [12, p. 168]. He, in his thoughts, strove to comprehend the essence of musical art, "....in connection with philosophy. Music seemed to him a source of life, a philosophical revelation that allowed him to think about the musical sense of being, which creates the prerequisites for a deep perception of life, rethinking reality, one's own achievements and creative possibilities" [13, p. 81].

It is in this creative searching environment of the Silver Age that the Gnesin system of musical education was developing.

After the Russian revolution in 1919, the Gnesin family granted their musical school to the state.

Here we should focus on a new period of the spiritual culture's development, the Soviet period (1917-1991). It had a great impact on organizational and administrative activity in the sphere of musical art. It also influenced all musical institutions, as well as the Gnesin educational institutions. This period completely changed society's mode of life and destroyed the foundations of old life. As a result of the rejection of religion and God, along with the formation and domination of a materialistic ideology over 70 years, society became isolated from spiritual values and ideals. Divinity was eradicated and replaced by Marxism-Leninism ideology. The totalitarian regime aspired to establish a unified collective monolithic culture. Famine, persecution, and oppression of those who thought differently, ultimately led to fear in society. Management and leadership forms gained state status and eliminated private property, entrepreneurship, management of a theater, and arts patronage. Moreover, creative freedom, even artist's creative self-determination, was brought under the state's control. All these factors destroyed the accumulated traditions of musical management in Russia.

The music industry was also industrializing at this time. Special controlling bodies were brought into existence to conduct strict supervising of art and culture. The Ministry of Culture, Soyuzkoncert, Goskoncert, philharmonics and concert organizations undertook all administrative functions. The implementation of the latter was often conducted formally, since the heads of the organizations rarely were aware of musicians' creative tasks and the essence of art issues. The core position in the sphere of music was occupied by social and ideological, cultural, and educational activities, and music was one of the most effective means of carrying these activities out. Free art and entrepreneurship were punishable since they were not supported by the government. The art intelligentsia, with certain rare exceptions, were almost entirely isolated from Russian emigration and capitalist countries. Festivals, concerts, and poetic readings were held mostly within the country in various halls, in small organizations, clubs, factory workshops, collective farms, and on sports fields in peacetime and wartime. These events had fixed subscription fees that were paid to actors. Educational institutions, schools, colleges, and universities were also encouraged to take part in performance activities. Young musicians attracted significant public interest alongside amateur art, which was booming and by all means promoted in the Soviet era of Russian history. The key objective of professional musicians was to draw common people to art, to meet their creative needs, and to offer them a possibility to realize their creative potential. In spite of the socialist ideology, the traditions of the Russian school were preserved and the music education of the younger generation was continued. 
The Gnesin Musical School was not spared from this process. In late 1920, the school was separated into two branches: the children's school and the musical college, which was named the Third Prominent Musical College. Reorganization of the school did not sever the connection between elementary and secondary stages of education. In 1925, the school was named after the Gnesins, in 1936 it was named the Gnesin State Musical College. Gradually, this college turned into one of the most well-known in the Soviet Union. The college tended to adhere to the musical traditions of the Silver Age in addition to love for the homeland, music, care for each other, and a fatherly attitude towards the students.

Like all Soviet people, music teachers during World War II displayed exceptional patriotism, love for their fellow citizens, in other words, all the true values that are passed throughout generations on a genetical level.

During the war, the college was the only educational institution that was not shut down. There were scheduled classes and teachers as well as students participated in charitable activities. More than a thousand concerts for the army were organized by students and teachers from the Gnesin college [14, p. 10].

No matter how difficult and challenging the situation was, Elena Gnesina never gave up music and the world of beauty that she wanted to reveal to her students. At the end of the war in 1944, the Gnesin Musical-Pedagogical Institute was founded. It was the first musical higher educational institution with a pedagogical focus. It was something that Gnesina had long dreamed about, realizing, that a country needs not only performers, but also teachers who could prepare professionals. Therefore, she attracted prominent musicians to work at the college. Among the first teachers invited to the college was Heinrich Neuhaus. At that time, he worked both at the Gnesin Institute (1944-1963) and at the conservatory.

At the beginning of the war, Neuhaus flatly refused to be evacuated for many reasons, one of them being that his mother-in-law was seriously ill and could not bear a long trip. Nevertheless, he was accused of defecting to the enemy and consequently arrested. What followed was an eight month prison sentence in the Lubyanka prison, which he managed to evade, thanks to Maria Yudina and Emil Gilels. Instead, Neuhaus was sent to the Urals, where he had been working in the Sverdlovsk conservatory until 1944. In 1944, as a result of petitions by the music society, Neuhaus managed to return to Moscow. At first, he was not allowed to work at the Moscow Conservatory. As a result, Gnesina asked him to work at her institute. For many years thereafter, he combined his work at these two educational establishments. On his beloved work, on the dedication to the profession of a musician-teacher, Neuhaus wrote a book "On the Art of the Piano Play", which he dedicated to his "colleagues, teachers, and students" [15, p.1].

Among his students at the Gnesin Musical-Pedagogical Institute were Lina Bulatova, G. Gordon., Leonid Brumberg, Oleg Boshniakovitch, V.Derevyanko, Evgeny Lieberman, Berta Kremenstein and many others; at the Moscow Conservatory he taught Sviatoslav Richter, Emil Gilels, Vladimir Krainev, Alexei Lyubimov, Yakov Zak, Lev Oborin, Alexei Nasedkin, and Vera Gornostayeva. His method of teaching was based on the spiritual insight into the content of the musical piece.

One of the main ideas that Neuhaus expressed was that technique is merely a means for the creation of an artistic image. There was always a warm and friendly air in the prom- 
inent teacher's classroom, students could freely communicate, and the teacher treated his students equally.

Neuhaus was highly regarded by Gnesina. Many other teachers and outstanding performers and composers worked under her supervision, such as Leonid Brumberg, Teodor Gutman, Aram Khachaturian, Timofei Dokshitzer, Maria Yudina and many other world renowned figures.

Gnesina cared greatly both for her teachers and her students. She realized that for good results to be achieved, it is important to place a great emphasis on the music education. From an early age, the most talented children were appointed to the most prominent teachers' classes.

The post-war years were a period of rapid development and expansion of the Gnesin Institute. The Special Music School (with a 10-year curriculum) was opened and affiliated with the Gnesin Institute. As a result, a musical establishment consisting of four educational institutions was created. It covered all stages of education (from pre-school to postgraduate education). In 1946, the main part of the building on Povarskaya street was built, in 1951 the the "Shuvalov house" was rebuilt, in 1958 the Concert hall was attached, and in 1974 a new building for the college was constructed. In 1948-1958, the college and schools were issued their own authorities and later, they were allotted separate buildings and autonomy from the institute. In 2011, the idea of continuity of the educational process was reconstituted in the Gnesis Academcy. The college was united with the academy, including the children's school.

In the Gnesin music complex new specialties arose that were dictated by modern trends. Here, for the first time in the country's history, a folk instruments department was opened (1948), folk choirmaster department (1966), musical comedy actors' department (1961), variety performance department (in 1973 - in the college, in 1984 in the institute), folk solo vocal studies department (1978), sound engineering department (1987), etc.

Intensive development of the whole Gnesin educational system started in the next stage of the spiritual culture development - the collapse of the USSR and transition to a capitalist society. The period from 1991 to the present day is conventionally entitled "the modern period". The transition to a market economy became a powerful impulse for the boom of musical management in Russia, which was mostly drawn upon Western management theories, such as transition to a voucher system, monetary economics, shock therapy, etc. At first, the adoption of Western theories was conducted without due consideration for the people's mentality, country's culture, and the level of its economic development. There was a general tendency towards global culture and its more sophisticated creative samples of managerial and administrative activities.

On the cusp of the $20^{\text {th }}$ and 21 th centuries there arose a huge number of companies and firms that operated in the music industry, launching popular projects mainly in pop-music (as well as folk, classical, and church music), which met the demands of both consumers and businessmen. Today, there are more than 70 private firms and companies in the area of concert business [16, p.476-92].

Modern spiritual culture revives the pre-revolutionary experience of past generations, including traditions of the Silver Age. Today, they represent a multifunctional fusion of neopaganism with orthodoxy, a combination of axiological, moral, and aesthetical matters of creative music projects. Russian spiritual culture even comprises Soviet tradi- 
tions in state governance. The latter often interfered with entrepreneurship by hampering intellectual and creative development. The process of a constant revival of religious beliefs is currently underway in Russia. According to Patriarch Kirill, the role of the state is as follows: "a moral state does not turn culture and knowledge into something that can be sold, especially at an unreasonable price because it always leads to social segregation and information inequality. A state supports an enlightening function of educational establishments, including higher ones, conducted in keeping with the spirit of mutual respect and assistance within the framework of national traditions and moral beliefs, influenced, among other things, by conventional religions" [III].

Under market economy conditions, the number of different projects, contests, and festivals has constantly been growing. This has given rise to a creative search for new opportunities and innovative technologies. At the same time, the general level of performance teams and individual performers' skills has notably risen. Managers have begun to select performers based more on strict demands and prepare them for both Russian and foreign audiences and the needs of society.

A social process of spiritual culture development is also mirrored in the modern environment of musical institutions. Thus, the Gnesin Musical - Pedagogical Institute from 1991 has been continuously expanding, giving rise to more and more new specialties, and in 1992 it was reorganized into the Gnesins Russian Academy of Music. Today, the academy is the only establishment that combines a pedagogical focus with a comprehensive professional musical education.

The Gnesins Russian Academy of Music is a fundamental educational institution which provides the best teaching and learning materials in Russia for a professional musical education. The academy provides a basic music education, additional training, and postgraduate studies in all fields of music and specializations. This allows for the production of creative projects in all music fields, such as folk, church, classical, pop, and jazz music. The academy contributes to the accumulation of the musical heritage passed through generations and promoted by means of various events that are conducted annually by the Gnesins Russian Academy of Music. All these factors prove that musical art is constantly becoming more popular and that the social, aesthetical, moral, and spiritual needs of society are being met [IV].

With the above-mentioned goals in mind, the academy holds a lot of various events that involve outstanding music teachers and talented students. It should be noted that their efforts are fully rewarded.

More than 15,000 musicians have graduated from the academy. Due to the combination of traditions of the late $19^{\text {th }}$ century with modern methodology and innovative technology, worldwide famous specialists graduated from the academy, such as Boris Tchaikovsky, Arno Babadjanian, Valentina Levko, Evgeny Svetlanov, Vladimir Fedoseev, V. Tukhmanov, Mikhail Tariverdiev, Evgeny Kisin, Daniel Kramer, Timofei Dokshitcer, Alexander Gradsky, Lyudmila Zykina, Valery Grokhovsky, Zara Dolukhanova, Alexandra Strelchenko, Nikolai Nekrasov, Iosif Kobzon, Gennady Rozhdestvensky, A.Eisen, and many others. Some of them were teachers at the Gnesins Institute (Academy).

Teachers, graduates, and students of the Gnesins Russian Academy of Music form their own musical bands, annually set up and participate in more than 350 events, and achieve great results in all fields of musical art while passing on the Gnesin traditions of the Silver Age to the next generations. The teachers, drawing on the Gnesin system of ed- 
ucation on every educational level (elementary, secondary or high), treat their students in a fatherly way, they teach and protect, take great care of them, give their hearts and souls to them, and foster the spirit of a creative search and perfection. All this contributes to the highest results in musical art and helps to reveal young talented musicians, which together lead to the further development and expansion of the Gnesin system of musical education in modern Russia.

\section{References}

1. Zorilova, Larisa. A. N. Scriabin. The Path to the Mystery. Spiritual-Creative Search in the Context of the Formation of Musical Art. Moscow: Akademicheskiy proekt Publ., 2020. (In Russian)

2. Berdiaev, Nicolai. Self-Cognition. Moscow: Eksmo-Press Publ.; Khar'kov: Folio Publ., 1998. (Antologiia mysli). (In Russian)

3. Zima, Tat'iana. "Russian Music Society as a Sociocultural Phenomenon in Russia of the Second Half of the $19^{\text {th }}$ and early $20^{\text {th }}$ centuries." Thesis of DC diss., Moskovskii gosudarstvennyi institut kul'tury Publ., 2015. (In Russian)

4. Kupert-Zima, Tat'iana. The Imperial House and the Russian Musical Society. Moscow: MGUKI Publ., 2014. (In Russian)

5. Sosedkina, Galina, and Irina Efimova. "People’s Conservatories as a Phenomenon of Music Education in Pre-Revolutionary Russia." Nauchnye issledovaniia i razrabotki molodykh uchenykh, no. 1 (2014): 16-20. Accessed October 06, 2018. https://cyberleninka.ru/article/n/narodnye-konservatorii-kak-fenomen-muzykalnogo-obrazovaniya-v-dorevolyutsionnoy-rossii. (In Russian)

6. Bulatova, Lina. Elena Gnesin's Piano School in the $21^{\text {st }}$ Century. Moscow: RAM im. Gnesinykh Publ., 2009. (In Russian)

7. Avdeeva, Anna, Nora Potemkina, and Vladimir Tropp. "Correspondence of R. M. Glier with the Gnessin Family. Part three". Uchenye zapiski Rossiiskoi akademii muzyki im. Gnesinykh, no. 4 (2019): 105-26.

8. Gnesina, Elena. "Memories of Rachmaninoff". Senar. Accessed March 12, 2018. https://senar.ru/memoirs/Gnesina/. (In Russian)

9. Arkhipova, Marina. "M.F.Gnesin and his Theory of 'Musical Reading". Analitika kul'turologii, no. 1/13 (2009): 90-6. Accessed February 03, 2018. https://cyberleninka.ru/article/n/m-f-gnesin-i-ego-teoriya-muzykalnogo-chteniya. (In Russian)

10. Bal'mont, Konstantin. "Sound ('The Finest Sound...')”. Accessed September 11, 2018. https://rupoem. $\mathrm{ru} /$ balmont/tonchajshij-zvuk-otkuda.aspx. (In Russian)

11. Sabaneev, Leonid. Memories of Scriabin. Afterword and comment. by S. Grokhotov. Moscow: Klassika-XXI Publ., 2000. (Muzyka v memuarakh). (In Russian)

12. Scriabin, Alexander. "Notes". In Russkie propilei: materialy po istorii russkoi mysli i literatury, ed. and comp. by Mikhail Gershenzon, 97-248. Moscow: M. I S. Sabashnikovykh Publ., 1919. (In Russian)

13. Zorilova, Larisa. "About Philosophical Outlook of A.N.Scriabin" Vestnik MGUKI, no. 6/74 (2016): 80-6. (In Russian)

14. Tropp, Vladimir, Evgenia Artemova, and Innokentii Barannikov, comp. Gnesinsky House: Chronicle of the War Years: Dedicated to the 65th Anniversary of the Victory in the Great Patriotic War of 1941-1945: collection of materials. Moscow: RAM im. Gnesinykh Publ., 2010. (In Russian)

15. Neuhaus, Heinrich. On the Art of Piano Playing. Notes of the Teacher. Afterword by Iakov Mil'shtein. $5^{\text {th }}$ ed. Moscow: Music Publ., 1988. (In Russian)

16. Dukov, Evgenii. "The Formation of the Concert Market" Russian Culture. 2000s: Collection of Materials, ed. by Elena Kostina, 476-92. St. Petersburg: Aleteia, 2012. (In Russian)

\section{Sources}

I. RGALI. F. 2954. Op. 1. Ed. khr. 107. [The Russian State Archive of Literature and Arts. Stock 2954. Inventory 1. Record 107]. (In Russian)

II. "Two Arbat Houses. Scriabin and Gnesins". Muzei Rossii. Accessed August 08, 2017. http://museum.ru/N41872. (In Russian) 
III. “Report of Patriarch Kirill for 19 $9^{\text {th }}$ Universal Russian Public Council”. Accessed November 10, 2015. http://www.patriarchia.ru/db/print/4267398.html.

IV. "Decree of the President of Russian Federation issued on January 16, 2017 № 13. On Approval of the Fundamentals of the State Policy of Regional Development of the Russian Federation for the Period until 2025”. Accessed September 18, 2018. http://www.kremlin.ru/acts/bank/41641.

Received: February 15, 2020

Accepted: May 28, 2020

Authors'information:

Galina V.Mayarovskaya — PhD, Professor; majar@bk.ru

Larisa S.Zorilova - Dr. Habil., Professor; zorilova@mail.ru

Daria G.Rodionova — PhD; sunshila@yandex.ru 